\title{
Characteristic of macroinvertebrates abundance in cascade-pond system at Universitas Indonesia Campus, West Java, Indonesia
}

\author{
Muthiah Fadillah Prinasti ${ }^{1,}{ }^{*}$, Dwita Sutjiningsih ${ }^{1}$, and Evi Anggraheni ${ }^{1}$ \\ ${ }^{1}$ Civil Engineering Department, Universitas Indonesia, 16424 Depok, Indonesia
}

\begin{abstract}
Catchment area of cascade-pond system at Universitas Indonesia (UI) campus is an area with high population density. The high population density has led to increasing impervious cover since it has to provide the housing needs. Increasing of impervious cover affected stream quality in the catchment area. The state of aquatic system quality can be assessed among others using biotic index and observed macroinvertebrates distribution. The management of UI campus plans to reduce the negative effect of decreasing the aquatic system quality by conducting audit the health state of cascade-pond system. The objective of this study is to examine the characteristics of macroinvertebrates abundance at cascadepond system at UI campus. Macroinvertebrates are commonly used as indicator of pollution level at aquatic system. Sampling is conducted using biomonitoring method, and is carried out at cascade-pond system, which consisted of six ponds, by two times repetitions. The identification of any individual macroinvertebrates caught during the sampling is conducted in the laboratory. The characteristics of macroinvertebrates were assessed based on Average Score Per Taxon (ASPT) Index dan Family Biotic Index (FBI).The results indicates that there is a tendency of improving diversity of macroinvertebrate in the downstream direction of the cascade-pond system.
\end{abstract}

\section{Introduction}

In order to become a green campus, UI built aquatic ecosystem covering approximately 30 hectares. It system consists of six ponds, which serves various purposes including as landscape element as well as natural laboratory for both academic staffs and students. Along with the population growth, its catchment area is becoming a region which a high population density. The population density has led to increasing impervious cover caused by the growing need for a place to stay. Increasing impervious cover can affect water quality in the catchment area [1]. After more than 20 years of service, the presence of contaminant in the cascade-pond is visible. Water contamination can occur due to human activities that eventually becomes runoff into water bodies [2].

* Corresponding author: muthiah.fadillah@ui.ac.id 
Biomonitoring is the systematic observation of organism (macroinvertebrates) and their response to environmental quality. Macroinvertebrates are widely used to determine the parameters of water quality because it has a sensitivity to each type of pollutant and has a quick reaction, do not have ability to migrate if there are alterations in the conditions of the waters, is arrested for visible and separated into several types [3].

The study aims to identify the abundance of macroinvertebrates found in the cascadepond system at Universitas Indonesia, Depok and to know the characteristics of macroinvertebrates by identifying the by Average Score Per Taxon (ASPT) and the Family Biotic Index (FBI). Most of biomonitoring were conducted in lentic waters like a river. This study is conducted in lotic waters by applying biomonitoring method in cascade pond system, UI Depok.

\section{Research Method}

\subsection{Reserach Site}

The research site is the cascade-pond system at Universitas Indonesia, Depok, West Java (Fig.1). The samples were taken in each inlet, middle and outlet of each pond. In this study, Rawa Besar Pond and Pladen Pond not included to futher analysis, because we the sampling conducted only within the campus area.

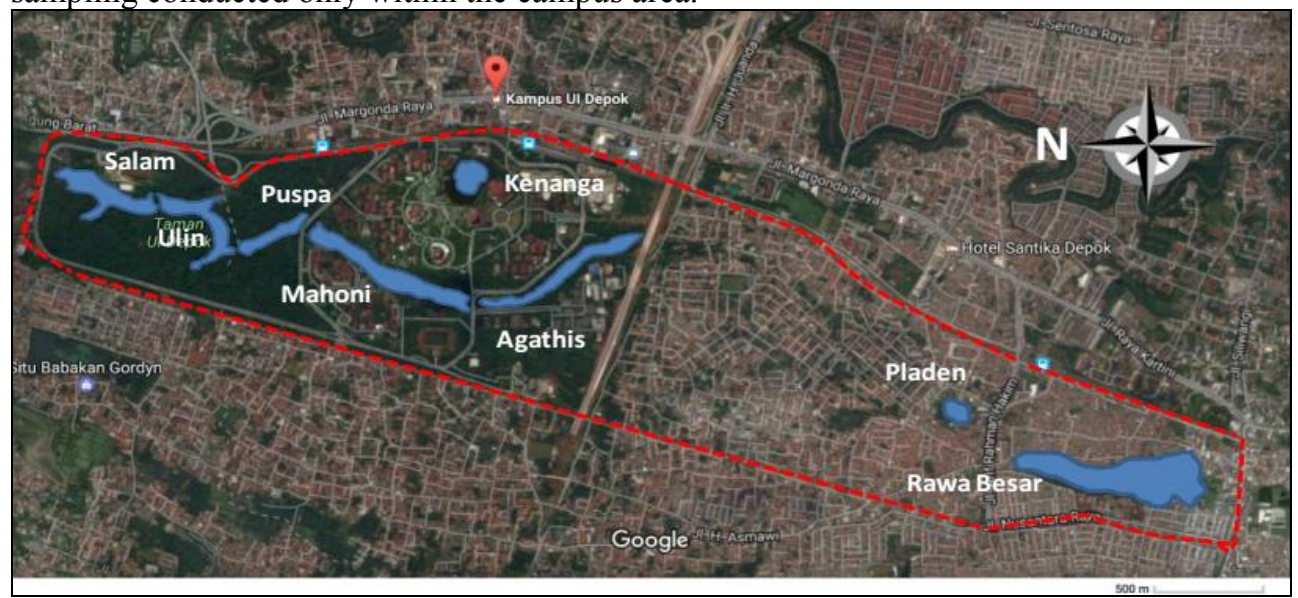

Fig. 1. Location of the study [4]

\subsection{Sampling Method}

Sampling macroinvertebrates needed some intruments and tools such as biomonitoring nets, sieve to separate the mud, glass bottle as a place to put samples, sample cards macroinvertebrates, and $\mathrm{pH}$ meters. Materials used during the macroinvertebrates sampling is $70 \%$ alcohol and formaldehide $4 \%$ to preserve macroinvertebrates. Macroinvertebrates sampling were carried out in each of the determined sample points. Macroinvertebrate sampling per sample point approximately 30 macroinvertebrates sought. The samples were preserved in the sample box for identification purpose. The identitification using microscope in laboratory [5].

\subsection{Analysis of Macroinvertebrates}

In the determination of water quality based on the biotic index, there are several indices that are commonly used, such as, Family Biotic Index (FBI), EPT Index, Biological Monitoring Working Party (BMWP), and Average Score Per taxon (ASPT). Each of these indices has different calculation methods, but still based on the diversity of the biota to be found. 


\subsubsection{Average Score Per Taxon}

ASPT index itself is a development of BMWP. Both biotic index was indices were developed in the United Kingdom. ASPT index can be calculated using the formula [6]:

$$
A S P T \text { Index }=\frac{\Sigma(B M W P \text { score } \times n)}{\Sigma n}
$$

Where:
BMWP score : scores of taxa found
$\mathrm{n} \quad$ : number of macroinvertebrates found during the sampling

The score in BMWP index ranges from 1 to 10. The higher figure score of BMWP, the more vulnerable or sensitive to contaminants. The results of the ASPT index that shows the quality of water is as follows:

Table 1. ASPT Score [3]

\begin{tabular}{|c|c|}
\hline ASPT Value & Water Quality Assessment \\
\hline$>6$ & Clean Water \\
\hline $5-6$ & Doubtful quality \\
\hline $4-5$ & Probable moderate pollution \\
\hline$<4$ & Probable severe pollution \\
\hline
\end{tabular}

\subsubsection{Family Biotic Index}

Family Biotic Index (FBI) is an index that is based on the level of taxa resistance to contamination. The score ranges from 0 to 10 , the higher the score the more resistant to pollutant [7]. The following is the FBI formula:

$$
F B I=\frac{\Sigma x \cdot t}{\Sigma n}
$$

Where:
FBI : Family Biotic Index
X : Macroinvertebrates found
$\mathrm{t} \quad$ : Scores against pollution tolerant taxa
$\mathrm{n} \quad$ : number of macroinvertebrates found during the sampling

The value of water quality index based on the Family Biotic Index are as follows:

Table 2. Family Biotic Index Score [7]

\begin{tabular}{|c|c|c|}
\hline $\begin{array}{c}\text { Family } \\
\text { Biotic } \\
\text { Index }\end{array}$ & $\begin{array}{c}\text { Water } \\
\text { Quality }\end{array}$ & Degree of Organic Pollution \\
\hline $0.00-3.75$ & Excellent & Organic Pollution Unlikely \\
\hline $3.76-4.25$ & Very Good & Possible slight organic pollution \\
\hline $4.26-5.00$ & Good & some organic pollution probable \\
\hline $5.01-5.75$ & Fair & Fairly substansial pollution likely \\
\hline $5.76-6.50$ & Fairly Poor & Substansial pollution likely \\
\hline $6.51-7.25$ & Poor & Very substansial pollution likely \\
\hline $7.26-10.00$ & Very Poor & Severe organic pollution likely \\
\hline
\end{tabular}




\subsection{The Influence of Riparian Buffer in Macroinvertebrata Abundance}

In Webster's New Universal Unabridged Dictionary, riparian is located on the bank of a natural watercourse (such as a river) or sometimes of a lake or a tidewater. Riparian zone are a combination of several landscapes, communities and environments that serve to understand the organization, diversity, and associated community dynamics in the aquatic ecosystem [8].

Many of the functions of the riparian zone are ecological functions. On the ecological function of the riparian zone serves as a sources of nourishment, as nutrient filters, and habitat [9]. As nutrient filters riparian zone serves as a biological buffer. Riparian forests are especially important sites for biotic accumulations of nutrients because transpiration may be quite high, increasing the mass flow of nutrient solutes toward root systems, and because morphological and physiological adaptations of the many flood-tolerant species facilitate nutrient uptake under low-oxygen condition [9]. Other than as a biological buffer, also serves as a Physical buffer. Which filters out sediments carried by runoff [10].

As a habitat, the riparian zone affects the abundance of macroinvertebrates. Riparian buffer zones could significantly reduce the impacts of deforestation on tropical streams. Macroinvertebrates are sensitive animals to existing pollution. Riparian buffer appeared to significantly reduce the effects of environmental degradation on benthic communities, as macroinvertebrate diversity [11].

\section{Result and Discussion}

Based on the sampling result, the abundance of macroinvertebrates found in each pond from upstream to downstream, namely, Kenanga, Agathis, Mahoni, Puspa, Ulin, and Salam are as follows:

Table 3. Macroinvertebrates found in cascade-pond.

\begin{tabular}{|c|c|c|c|c|c|c|}
\hline \multirow{2}{*}{ Makroinvertebrates } & \multicolumn{6}{|c|}{ Amount macroinvertebrates in each cascade-pond system } \\
\cline { 2 - 7 } & Kenanga & Agathis & Mahoni & Puspa & Ulin & Salam \\
\hline Filopalodina javanica & 3 & 1 & 63 & 24 & 20 & 13 \\
\hline Melanoides tuberculata & 39 & 2 & 13 & 10 & 1 & 1 \\
\hline Tarebia granifera & 0 & 0 & 8 & 1 & 0 & 0 \\
\hline Gyraulus sp. & 0 & 19 & 0 & 0 & 0 & 1 \\
\hline Indoplanoubis & 0 & 1 & 0 & 0 & 0 & 0 \\
\hline Lymnea Rubignosa & 0 & 3 & 0 & 0 & 0 & 0 \\
\hline Pilla scutata & 3 & 1 & 21 & 0 & 12 & 17 \\
\hline Pomacea canaliculata & 3 & 1 & 4 & 0 & 1 & 0 \\
\hline Parathelphusa convexa & 0 & 3 & 1 & 2 & 3 & 10 \\
\hline Parathelphusidae & 0 & 0 & 6 & 5 & 0 & 22 \\
\hline Gyrinius sp. & 0 & 47 & 0 & 0 & 0 & 13 \\
\hline Hydrophillus larva & 0 & 1 & 0 & 0 & 0 & 0 \\
\hline Hydrophorus $s p$. & 0 & 1 & 0 & 0 & 0 & 0 \\
\hline Corixa sp. & 0 & 3 & 0 & 1 & 1 & 3 \\
\hline Notonecta sp. & 0 & 1 & 0 & 0 & 0 & 4 \\
\hline Ilyocoris cimicoides & 0 & 0 & 0 & 0 & 2 & 2 \\
\hline Gerris $s p$. & 0 & 2 & 0 & 0 & 30 & 7 \\
\hline Sialis larva & 0 & 1 & 0 & 0 & 0 & 0 \\
\hline Aeshna sp. & 0 & 1 & 0 & 1 & 0 & 0 \\
\hline Gomphus $s p$. & 0 & 1 & 0 & 2 & 0 & 0 \\
\hline Nereiridae & 0 & 1 & 0 & 0 & 0 & 0 \\
\hline Tubificidae & 0 & 5 & 1 & 0 & 0 & 0 \\
\hline Total & 48 & 95 & 117 & 46 & 70 & 93 \\
\hline
\end{tabular}


After processing by macroinvertebrates found ASPT value and FBI obtained as follows:

Table 4. ASPT and FBI Value

\begin{tabular}{|c|c|c|c|c|c|c|}
\hline \multirow{2}{*}{ Score } & \multicolumn{7}{|c|}{ Cascade-Pond System } \\
\cline { 2 - 7 } & Kenanga & Agathis & Mahoni & Puspa & Ulin & Salam \\
\hline ASPT & 3.19 & 4.27 & 4.77 & 5.39 & 4.98 & 5.08 \\
\hline FBI & 6.98 & 5.43 & 6.41 & 5.93 & 5.73 & 5.84 \\
\hline
\end{tabular}

ASPT values of Kenanga pond amounted to 3.19 indicating that is heavily polluted. Similarly, base on Family Biotic Index with a value of 6.98. The macroinvertebrates are found largely a group of gastropods. If in a body of water gastropods are dominant, then the waters classified as polluted. The riparian of Kenanga has been converted into riprap walls. If a body of water has undergone development, it will reduce the diversity of macroinvertebrates.

The ASPT value of Agathis pond is 4.27 , which indicates the waters are moderately polluted. The same conclusion when viewed from Family Biotic Index with a value of 5.43. If seen from the distribution of macroinvertebrates in Agathis, the types of macroinvertebrates are quite vary, as including Oligochaeta, Gastropods, Crustacean, and Insecta. Oligochaetta and Gastropods are indicators of pollution. The most probable reason that Agathis has a better FBI score is the condition of its riparian, which is still in natural condition.

Mahoni pond has two inlets, from Agathis and from outside the campus, while its wall is already constructed by using riprap. The ASPT value is equal to 4.77, which indicated that Mahoni is moderately polluted. Similarly by Family Biotic Index the value of 6.41 indicates a rather heavyly polluted. The dominant macroinvertebrates found are gastropods, almost $93 \%$ are snails. The gastropod signifies the polluted waters. Similarly, if seen from the riparian condition of Mahoni, which has undergone development, will influence the spread of macroinvertebrates.

Puspa pond located downstream of Mahoni. The conditions of the riparian are still natural, surrounded by city forests. The ASPT value of Puspa is 5.39, which indicates lightly polluted conditions. However, if assessed based on Family Biotic Index, Puspa has a value of 5.93 indicating lightly heavy polluted waters. Distribution of macroinvertebrates consists of Gastropods, Crustaceans, Insecta, and Dragonfly larvae.

Ulin pond has three inlets. The first comes from Puspa, the second; and the third inlets come from outside the campus. Based on the ASPT, Ulin has a value of 4.98 which means Ulin is moderately polluted. A Family Biotic Index value of 5.73, indicates that the waters is moderately polluted. Distribution of macroinvertebrates at Ulin consists of Insecta, Gastropods, and Crustaceans. Although the riparian of Ulin still surrounded by city forest, the inlet side wall is already constructed by using riprap.

Salam pond has two inlets, first comes from the Ulin and the second comes from outside the campus. Based on ASPT value of 5.08, Salam is lightly polluted. While based on Family Biotic Index value of 5.84, meaning that Salam is polluted rather bad. Macroinvertebrates found in Salam is of Crustaceans, Gastropods, and Insecta. Riparian zone of Salam is city forest, while at the side of the wall has been constructed by using riprap. 
The overall distribution of macroinvertebrates in the cascade-pond system is presentedin the following figures:

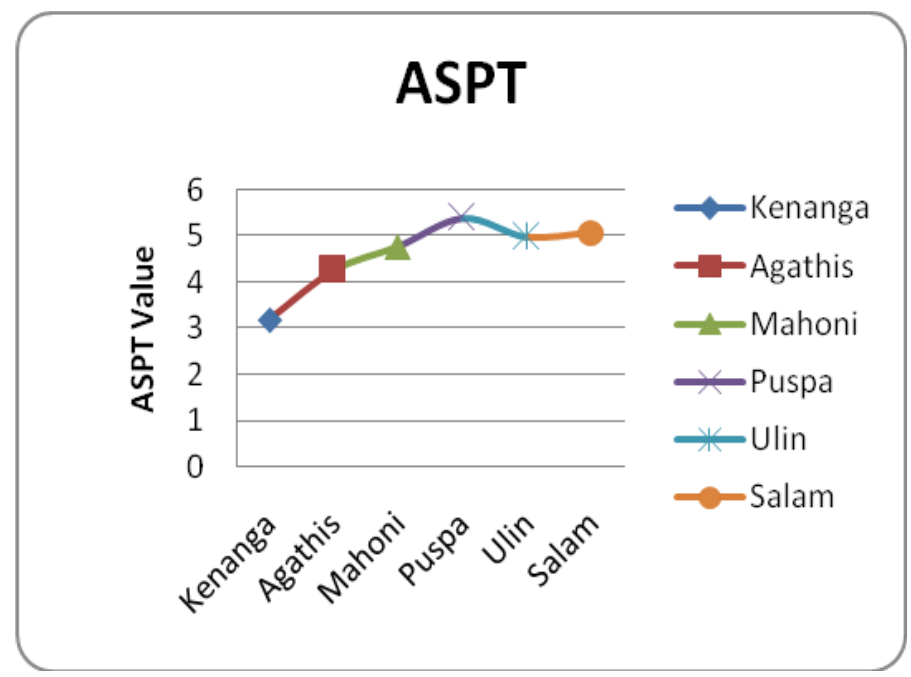

Fig. 2. ASPT Index of Cascade-pond System

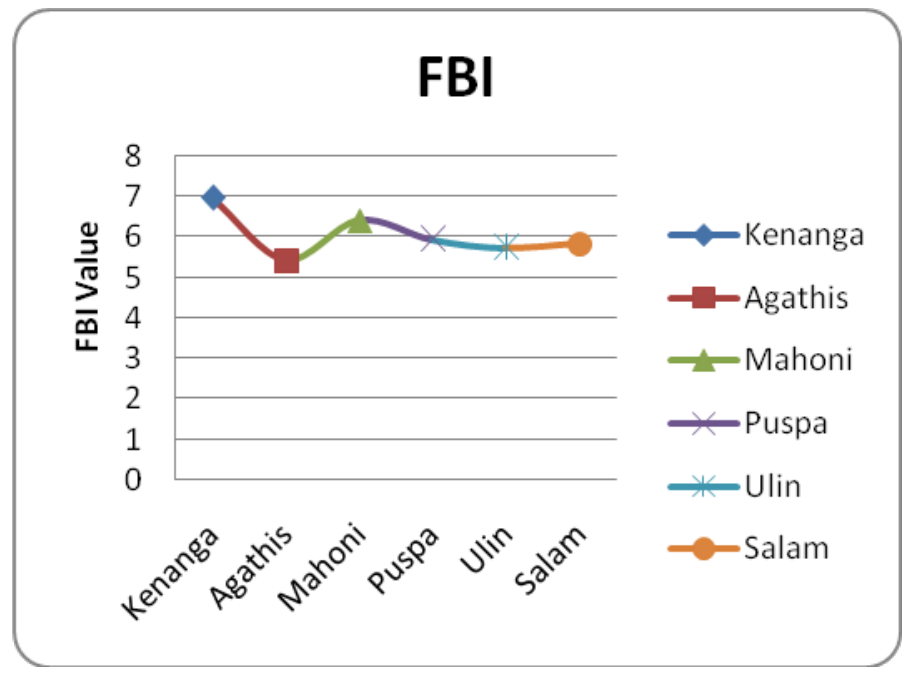

Fig. 3. Family Biotic Index of Cascade-pond System

Considering the cascade-pond system as a whole, in the downstream direction, in general, the distribution of macroinvertebrates and water quality is getting better. However, valuation by the ASPT index, cascade-pond Puspa have the most excellent value than the others. When viewed as a cascade-pond system, Salam, the most downstream pond should be better than Puspa. The most probable reasons are the riparian of Puspa is still natural, while part of the Salam wall is already constructed by using riprap.

Although in general Salam has better macroinvertebrates distribution, Agathis has the best FBI score. Family Biotic Index is essentially based on the level of taxa resistance to contamination. In Agathis encountered Gomphus Sp and Aeschna Sp, which is the larvae of 
a dragonfly. They are susceptible to pollution. If one of these macroinvertebrates is found, meaning that Agathis is still under natural condition.

\section{Conclusion}

Based on the stages and research methods undertaken, it can be concluded as follow:

1. Based on ASPT index in general cascade-pond system in Universitas Indonesia is in medium contaminated condition. Except in the Kenanga, which is in a heavy polluted state. Puspa and Salam are lightly contaminated.

2. Based on the Family Biotic Index the condition of Universitas Indonesia's cascadepond is slightly polluted. Except cascade-pond Kenanga, which is heavily polluted. Whereas, Agathis and Ulin are in medium contaminated condition.

3. In general the spread of macroinvertebrate abundance is increasing in the downstream direction of the cascade-pond system, and also is the diversity

4. Based on the ASPT Index, Puspa is the best, while based on FBI, Agathis is the best. The difference is influenced by the condition of the riparian zone of each pond. The abundance of macroinvertebrate is also affected by riparian zone.

Acknowledgements are addressed to Universitas Indonesia for giving financial support through the PITTA 2017 funding scheme. A special thanks to Drs. Wisnu Wardhana, M.Si as Freshwater Ecology Lecturer to help us identify macroivertebrates and 16 Surveyors which consist of college students and staffs of Civil Engineering Department Universitas Indonesia in conducting field survey.

\section{References}

1. Center for Watershed Protection, Watershed Protection Research Monograph No.1: Impacts of Impervious Cover On Aquatic Systems (Center for Watershed Protection, Ellicot City, 2003).

2. J. Sartor, G. Boyd, F. Agardy, J. Wat. Poll. Cont. Fed 46, 458 (1974)

3. S. Mandaville, Benthic Macroinvertebrates in Freshwaters Taxa Tolerance Values, Metrics, and Protocols (Soil \& Water Conservation Society of Metro Halifax, Nova Scotia, Canada, 2002)

4. D. Sutjiningsih, Int. Jour. Tech 1, 145 (2017)

5. W. Wardhana. Metoda Prakiraan Dampak dan Pengelolannya pada Komponen Biota Akuatik (Universitas Indonesia, Jakarta, 2006)

6. W. Wardhana. Perubahan Lingkungan Perairan dan Pengaruhnya Terhadap Biota Akuatik (Universitas Indonesia, Jakarta, 1999)

7. F. Haurer, G. Lamberty, Methods in Stream Ecology: Second Edition (Elsevier, Academic Press, California, 2007)

8. S. Gregory, F. Swanson, W. Mckee, K. Cummins, J. Bio. Sci 41, 540 (1991)

9. R. Naiman, H. Decamps, Annu. Rev. Ecol. Syst 28, 621 (1997)

10. T. Dillaha, R. Reneaus, S. Mostaghimi, D. Lee, Trans. Am. Soc. Agric. Eng 32, 513 (1989)

11. C. Lorion, B. Kennedy, J. Fresh. Bio 54, 165 (2009) 